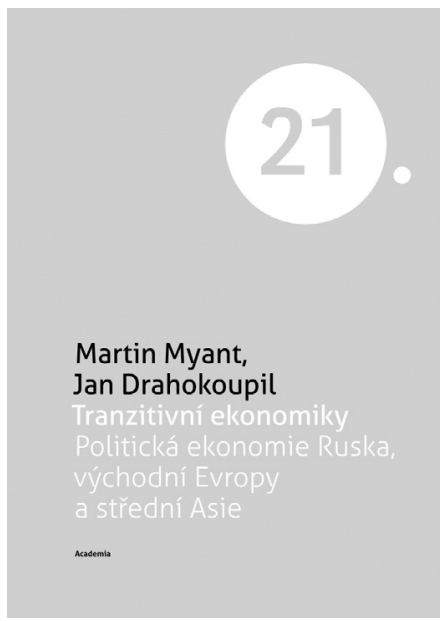

\title{
TRANZITIVNÍ EKONOMIKY: POLITICKÁ EKONOMIE RUSKA, VÝCHODNÍ EVROPY A STŘEDNÍ ASIE
}

\author{
Autoři: Martin Myant, Jan Drahokoupil \\ Nakladatelství: Academia, 2013.
}

V roce 2013 se do českých odborných knihkupectví dostala kniha autorů M. Myanta a J. Drahokoupila Tranzitivní ekonomiky: politická ekonomie Ruska, východní Evropy a střední Asie, kterou vydalo respektované nakladatelství Academia. Kniha je českou verzí anglicky psaného originálu Transition Economies: Political Economy in Russia, Eastern Europe, and Central Asia vydaného v roce 2011 nakladatelstvím John Wiley \& Sons (překlad tým prof. M. Žáka).

Publikace nabízí ucelený pohled na průběh transformačního procesu ekonomik v makroregionu bývalého východního bloku. Autoři zajistí pozornost čtenáře hned $v$ úvodu knihy, kdy vcelku netradičně (minimálně v místním pojetí strukturace knih a článků), ale velmi zajímavě a funkčně, nabídnou „závěrečný účet“ transformačního procesu. Bez ohledu na možnost, že některé závěry by $v$ akademickém $v$ akademickém prostředí mohly být předmětem polemiky, je třeba ocenit sílu autorů a jejich schopnost formulovat jasná nealibistická stanoviska. Vlastní text autoři začínají vstupní syntetickou charakteristikou fungování státního socialismu. Tuto pasáž ocení zejména mladší ročníky čtenářŭ, kteří nemají reálnou zkušenost se životem v této době. Následuje hlavní předmět zájmu publikace a to detailní postižení specifik transformačního procesu $v$ jednotlivých národních ekonomikách v makroregionu. $V$ závěrečné pasáži dali autoři prostor diskusi soudobých vývojových forem kapitalismu i prostorové diferenciaci projevů finanční krize.

Kniha je velmi zdařilým počinem $v$ oblasti poltické ekonomie a ekonomické komparativní analýze v perspektivě národních států. Mezi prínosy díla patří systematická sumarizace poznatků o jednotlivých ekonomikách i formulace jasných hodnotících stanovisek o jednotlivých aspektech jejich vývoje. Text je navíc doplněn velkým počtem grafů a tabulek, které nabízejí v přehledné formě základní data o vývojových parametrech národních ekonomik. Autoři dokonale využívají své pozice extrémně nadstandardně informovaných vnějších pozorovatelů, kdy jejich dlouhodobý výzkumný zájem o území (M. Myant) či soudobé působení v zahraničí (J. Drahokoupil) vytváří ideální podmínky pro nadhled, syntézu a generalizaci. Knihu je nutno primárně doporučit zájemcům z řad odborné veřejnosti, ale způsob pojetí tématu je zvolen tak, dle zvyklostí v anglo-saském prostředí, že může pritáhnout zájem i širších mas čtenárư.

RNDr. Jaroslav Koutský, Ph.D.

Univerzita J. E. Purkyně v Ústí nad Labem

Fakulta sociálně ekonomická 